\title{
Figurines de moda y formación del gusto en las élites costarricenses a fines del siglo XIX (1889-1896)
}

\author{
Fashion plates and the formation of taste in the Costa Rican \\ elites at the end of the nineteenth century (1889-1896)
}

Ángela Hurtado

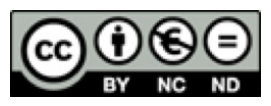

Esta obra está bajo una licencia Creative Commons Reconocimiento-No comercial-Sin Obra Derivada 
Artículos

\title{
Figurines de moda y formación del gusto en las élites costarricenses a fines del siglo XIX (1889-1896)
}

\author{
Fashion plates and the formation of taste in the Costa Rican \\ elites at the end of the nineteenth century (1889-1896)
}

\author{
Ángela Hurtado² \\ Universidad de Costa Rica \\ angela.hurtado@gmail.com
}

Recibido: 28 de octubre de 2016 Aprobado: 15 de marzo de 2017

\begin{abstract}
Resumen
El artículo detalla la relación visual entre las revistas ilustradas especializadas en moda, llamadas figurines, y la manera en que se expresaba un gusto "afrancesado" en la vestimenta de las clases altas en Costa Rica a finales del siglo XIX. Se basa en criterios de Pierre Bourdieu sobre el gusto y de Norbert Elias sobre el proceso civilizador para establecer las asociaciones entre la información que se diseminaba con los figurines y la adopción de ciertas modas en la Costa Rica finisecular. Se hace una revisión de un acopio privado de figurines de moda, que incluye las revistas La Estación, La Moda Elegante y La Revista Ilustrada de Nueva York, publicadas entre 1889 y 1896. Se compara la información presentada en estos figurines con avisos comerciales en los periódicos costarricenses y retratos fotográficos del mismo período.
\end{abstract}

Palabras clave: moda siglo XIX; figurines de moda; gusto; revistas de moda; Historia de la moda.

1 La autora expresa su agradecimiento al Archivo Histórico Musical de la Universidad de Costa Rica por haberle permitido el uso del equipo necesario para digitalizar el acopio de figurines de moda originales que son el objeto de esta investigación.

2 Investigadora del Instituto de Investigaciones en Arte (IIARTE) y profesora de la Escuela de Artes Plásticas, ambos en la Universidad de Costa Rica. 


\begin{abstract}
This article describes the visual relationship between fashion magazines and the manner in which a taste for French style was expressed in the clothing of the higher classes in late nineteenth-century Costa Rica. The theoretical basis for the article rests in Pierre Bourdieu's concept of "taste" and Norbert Elias' concept of "the civilizing process" to establish the relationships between the information that was disseminated through the fashion magazines and the adoption of certain trends in fashion in late nineteenth-century Costa Rica. The article includes a review of a private collection of original fashion magazines, which includes numbers of La Estación, La Moda Elegante and La Revista Ilustrada de Nueva York, published between 1889 and 1896. The information on the magazines is compared to advertisements in Costa Rican newspapers and photographic portraits of the same period.
\end{abstract}

Keywords: fashion; nineteenth century; fashion magazines; taste; History of costume. 


\section{Introducción}

En Costa Rica, las revistas de moda han sido poco estudiadas. En otros países se ha incorporado la historia de las publicaciones periódicas sobre moda a la corriente más general de estudio de la Historia de la vestimenta, pero esto no ha ocurrido de la misma forma en nuestro país. Los autores que se han preocupado por el estudio de la cultura material son quienes le han dedicado un espacio a la ropa en sus escritos, aunque no se ha producido un estudio más minucioso de los figurines de moda que llegaban a Costa Rica. Estas publicaciones resultan útiles porque ofrecían información actualizada sobre las tendencias extranjeras más importantes de la época en que se imprimían y recomendaciones sobre cómo vestirse para las diferentes ocasiones sociales que, a fines del siglo XIX, les eran más accesibles a las clases altas en diversas partes del mundo.

Asimismo, los figurines de moda se tornaban muy valiosos por el detalle de sus ilustraciones, que permitían informarse de cada elemento novedoso de un traje. En muchos casos, estas revistas incluían las instrucciones y los patrones que se necesitaban para copiar los nuevos estilos. Además, sus anuncios comerciales informaban de los objetos que podían adquirirse para el cuidado personal, para aumentar el guardarropa y para llevar a cabo las labores femeninas que se apreciaban en la revista. De este modo, tales publicaciones difundían ideas muy específicas sobre las prendas, el gusto de la época y el modo de presentarse en sociedad. La vestimenta es una de las formas visuales más efectivas de construir y comunicar la pertenencia a una clase social. Los figurines de moda ayudaban a las lectoras a encontrar las formas "correctas" de dar a entender su ubicación de clase, así como también ilustraban acerca de las maneras apropiadas de conducirse en sociedad con un traje. Esto podía resultar muy importante pues la correcta socialización de la mujer de clase alta en el siglo XIX le permitía desplazarse por los espacios domésticos y exteriores con soltura y gracia, a pesar de los complicados trajes con los que se vestía. En este artículo se hará un énfasis especial en cómo los figurines ayudaban a diseminar los usos "correctos" de la vestimenta y en cómo contribuían con el proceso civilizador de las clases altas en Costa Rica.

Además, se busca describir la importancia de los figurines de moda en la difusión de los gustos europeos hacia Costa Rica. Se reconoce el rol que estas publicaciones desempeñaron en formar el gusto de sus lectores, quienes podrían utilizar la información contenida en sus páginas para comprender las nuevas modas, los usos y las costumbres europeos -en particular, franceses- que se encontraban vigentes. El figurín de moda también se concibe como parte de una estructura cultural más amplia, cuya finalidad de difundir el gusto europeo estaba avalada por las élites gobernantes en Costa Rica.

Durante el período liberal en la segunda mitad del siglo XIX, las élites costarricenses 
otorgaron una gran importancia al gusto europeo, como parte de un proyecto de utilizar la cultura para legitimar el poder político. Según Arce Ovares (comunicación personal, 27 de marzo del 2014), el proyecto político del liberalismo estaba basado en el orden y el progreso: el orden servía para instaurar una normativa que legitimase el poder, mientras que el progreso utilizaba la cultura como un concepto elitista europeizante que se imponía desde las élites hacia abajo en la jerarquía social. La emulación de la cultura europea se cristalizaba en las publicaciones periódicas impresas en Costa Rica o que llegaban por diversos medios. Tales revistas difundían conceptos estéticos y formas de comportamiento que ayudaban a normalizar los usos europeos en nuestro país.

De ese modo, los figurines de moda y otros periódicos contribuían a preparar la cultura costarricense para asimilar el imaginario europeo y para expresar las distinciones de clase amparándose en la forma en las que estas diferencias se evidenciaban según el gusto de las clases altas europeas. Por lo tanto, para brindar una base teórica a este proyecto, se utilizó el trabajo de los científicos sociales Pierre Bourdieu y Norbert Elias. Ambos trabajaron con conceptos relacionados con las clases sociales, la manera en la que estas se conforman gracias a sus elecciones de consumo, y cómo este proceso se desenvuelve con el tiempo.

El análisis de la información obtenida de los figurines de moda se produjo a la luz de los conceptos de habitus ${ }^{3}$ y gusto ${ }^{4}$, propuestos por Pierre Bourdieu, y del concepto de proceso civilizador ${ }^{5}$, acuñado por Norbert Elias. En términos generales, estas ideas resultaron útiles para comprender los datos obtenidos de las revistas porque permiten articular el contenido de los figurines

3 El habitus se define como la orientación de las elecciones y las prácticas que surge en una persona debido a sus condiciones económicas, culturales, educativas, etc. El habitus de clase es el sistema de disposiciones que orientan las elecciones y las prácticas de un grupo de personas que comparten las mismas condiciones de existencia (Bourdieu, 2007).

4 El gusto está relacionado con las predilecciones por ciertos objetos o actividades y la manera en que estas elecciones se perciben dentro de una sociedad. Así, el individuo valora los costes de seleccionar un objeto o actividad contra los posibles beneficios sociales, físicos, simbólicos o de distinción que pueda obtener. Las elecciones mediadas por el gusto también ubican al individuo en una determinada clase social (Bourdieu, 2016, pp. 22-23).

5 El proceso civilizador describe los cambios que se han producido en ciertas conductas con el paso del tiempo, dentro de ámbitos específicos de las relaciones humanas. Este es un proceso que Elias considera motivado en parte por la vergüenza hacia comportamientos anteriores que se consideran "incivilizados" en un momento específico de la historia humana. Para Elias (2016), la vergüenza en este caso es un tipo particular de ansiedad que se deriva del miedo a la degradación social. Así, la vergüenza es un motor para la aceptación del cambio en las conductas sociales: cuando alguien descubre que su forma de comportarse no se adecúa a lo que el resto hace, se siente inferior y avergonzado, lo que facilita que adopte los nuevos hábitos. 
con dos aspectos importantes: en primer lugar, las prácticas vestimentarias europeas (específicamente parisinas) de las clases altas; en segundo lugar, la forma en la que estas prácticas se exportaban hacia otros países como una forma de denotar el gusto asociado con un alto status social.

Los conceptos de Bourdieu y Elias pueden ser utilizados para trabajar el tema de la moda, tal como los mismos autores lo hicieron en sus propios textos ${ }^{6}$. Por una parte, las fuentes documentales de este trabajo de investigación ofrecen pautas -escritas y visuales-acerca de cómo debe presentarse y comportarse una mujer en la sociedad occidental de finales del siglo XIX. Estos consejos se relacionan con el ámbito de las relaciones sociales, mediadas por el proceso civilizador: por ejemplo, versan sobre temas como la presentación de la vestimenta en distintas ocasiones sociales, así como ilustran acerca de las maneras consideradas correctas de combinar materiales, colores y accesorios en un atuendo. Por otra parte, los ideales que se reproducen en esas revistas de modas corresponden a las clases altas. Bourdieu propone que el gusto de la clase hegemónica será considerado el gusto legítimo en un momento determinado. Así, las elecciones de las clases altas en el período estudiado serán consideradas de "buen gusto", es decir, de un gusto considerado socialmente legítimo. Esto es algo que se tornará esencial para entender el campo de la moda, el cual también puede ser estudiado como parte de las prácticas que legitiman y reproducen las jerarquías sociales.

De tal manera, en este artículo se utilizarán los términos "formación del gusto" como la unión de los conceptos de gusto y de proceso civilizador. Esos términos se refieren a las operaciones necesarias para orientar el gusto de un grupo específico hacia ciertas ideas estéticas y formas particulares de comportamiento, que en un momento histórico se consideran más apropiadas para denotar la clase social elevada a la que el grupo pertenece. De este modo, los figurines de moda y sus contenidos se abordarán como repositorios confiables para sus lectores, cuyos testimonios provenían de la observación de los usos europeos más actuales, y que ofrecían la información necesaria para amoldar el gusto hacia la corriente europeizante.

\section{El acopio de figurines de moda}

En este proyecto se utilizó una colección personal de figurines de moda como base documental. Los figurines que se estudiaron son publicaciones periódicas enfocadas en temas relacionados con la vestimenta y que podían incluir textos, ilustraciones y anuncios publicitarios sobre las nuevas tendencias para las distintas ocasiones; las formas de confección de prendas y accesorios; las instrucciones y los patrones destinados a las labores femeninas; y consejos para

6 Pierre Bourdieu escribió el artículo "Alta costura, alta cultura”; Norbert Elias menciona casos específicos como los pañuelos o las pijamas en El proceso civilizador. 
seleccionar y combinar los atuendos completos. El figurín era popular porque solía incluir ilustraciones que servían para observar minuciosamente los detalles de la confección de las nuevas modas. Algunas ediciones de estas revistas incluían los patrones orientados a confeccionar las prendas que aparecían en el figurín. Las revistas que se analizaron en este proyecto fueron $L a$ Estación (fig. 1), La Moda Elegante (fig. 2) y La Revista Ilustrada de Nueva York (fig. 3) correspondientes al período 1889-1896.

Figura 1. Portada de La Estación

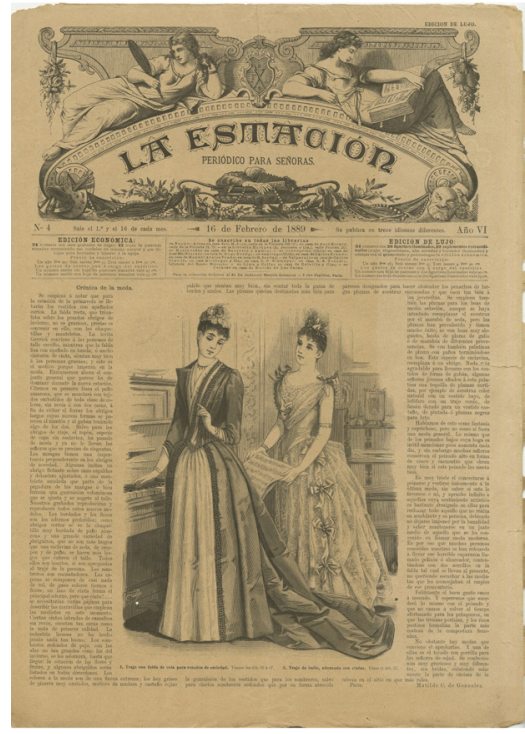

Fuente: La Estación (febrero 1889).
Figura 2. Portada de La Moda Elegante

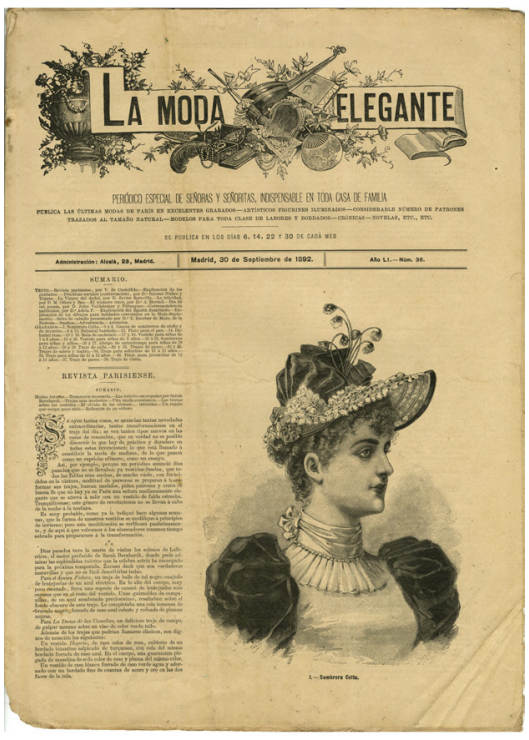

Fuente: La Moda Elegante (setiembre 1892).
Figura 3. Portada de La Revista Ilustrada de Nueva York

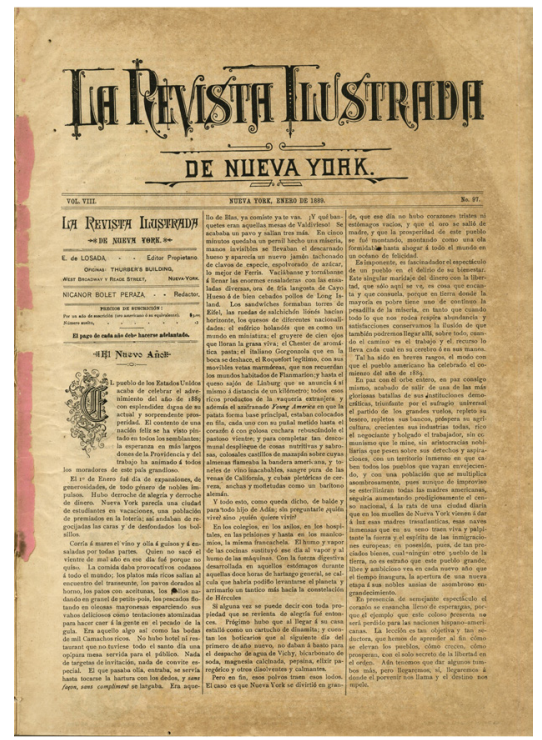

Fuente: La Revista llustrada de Nueva York (enero 1889).

La escogencia de este período en las publicaciones de moda responde a dos razones principales. En primer lugar, el hecho de que estos figurines antiguos hayan sobrevivido en relativamente buenas condiciones y que, además, sean de fácil acceso para esta investigación son condiciones de gran relevancia. En segundo lugar, la transición entre las décadas de 1880 y 1890 se demuestra en cambios particulares en la silueta femenina: el abandono de las estructuras internas que dan volumen a la falda, a finales de 1880; y la aparición, a inicios de los años de 1890, de las llamadas "mangas jamón" (mangas con gran volumen en la parte superior, que se angostan al llegar al codo). Este tipo de cambios pueden identificarse en los retratos e imágenes de mujeres costarricenses del período.

La colección que compone la muestra es distinta de lo que se encuentra en el Archivo Nacional y en la Biblioteca Nacional. A diferencia de los acopios en estas instituciones, los figurines de 
la muestra de esta investigación no fueron impresos en Costa Rica. Estas publicaciones provenían de Europa o de los Estados Unidos, por lo que conforman una muestra poco común: sus contenidos e imágenes llegaban a nuestro país directamente de las ciudades consideradas más importantes en términos de creación de nuevas tendencias en la moda a fines del siglo XIX. De este modo, la información no se traducía a la realidad climática ni a los usos y costumbres de otros países, sino que indicaba al lector de qué prendas se llevaban y cómo se debían lucir según el gusto europeo.

Las publicaciones del acopio arribaban a nuestro país mediante suscripciones. Es común encontrar, en las mismas revistas, anuncios que hacían referencia a esta modalidad de difusión, en la que un agente autorizado (generalmente, el dueño de una librería o un negocio similar) recopilaba una lista de suscriptores locales, recogía los abonos anuales y remitía esta información a las oficinas de la revista en Europa o los Estados

Figura 4. Distintivo en la tapa de la encuadernación de $L a$ Revista llustrada de Nueva York

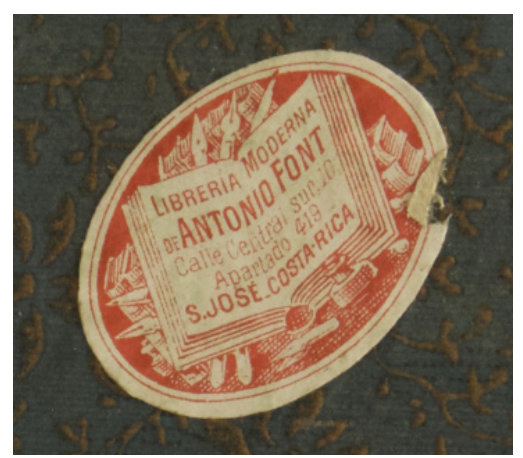

Fuente: La Revista llustrada de Nueva York, reverso de la tapa.

Figura 5. Anuncio de la Librería Moderna en El Pabellón Español

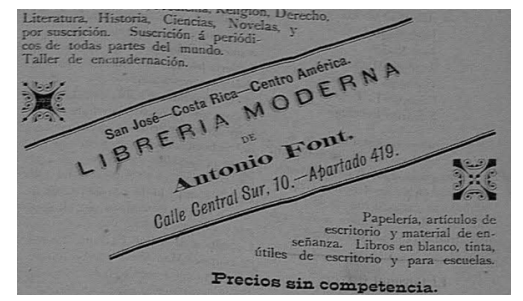

Fuente: El Pabellón Español (10 de noviembre de 1895, p. 35$)$.
Unidos. Posteriormente, los ejemplares se enviaban a los países hispanoamericanos según la frecuencia con que se publicasen. Vega Jiménez (1995) plantea que los periódicos privados (no asociados al gobierno) se distribuían en Costa Rica en los talleres o las tiendas. Allí, los corresponsales debían "llevar el control de la suscripción, cobrar el costo de la misma, distribuir el impreso, e incluso enviarlo a casa de los compradores y recoger manuscritos de personas que desean ver impresas sus ideas" (p. 160). La mayoría de estas publicaciones eran muy costosas y no estaban al alcance del grueso de la población.

Los ejemplares de La Revista Ilustrada de Nueva York del año 1889 están encuadernados juntos y aún se conserva un pequeño distintivo que reza: "Librería Moderna de Antonio Font - Calle Central sur 10, Apartado 419- San José, Costa Rica" (fig. 4). Se encontraron anuncios de esta librería en el periódico costarricense El Pabellón Español (fig. 5). En el número del 10 de noviembre de 1895, este periódico presenta un anuncio de la Librería Moderna, que incluye el texto: "Suscrición á periódicos de todas partes del mundo. Taller de encuadernación [sic]". Así, es posible afirmar que esta librería manejaba las suscripciones a La Revista Ilustrada de Nueva York y encuadernaba los números recibidos cada año.

Tanto La Moda Elegante como La Estación podían adquirirse mediante suscripciones con agentes autorizados 
Figura 6. Anuncio de La Estación, en El Correo de Costa Rica

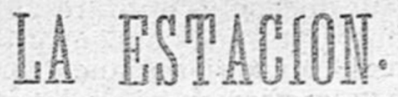

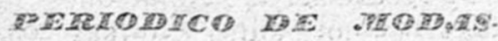

EDICION DE LUJO.

PARA SENORAS.

24 NUMEROS con mas de 2,000 grabados al año, conteniendo modelos de toda clase de prendas de vestir para señoras, señoritas y niños; ropa blanca y 20. pa de cama, servicios de mesa y de tora. dor, ete. ete-Ademis toda clase de la. bores y borclados.

12 HOIAS de patrones trazados, conteniendo ademas de mo infinidad de iniciales, cifras $y$ alfabetos, 200 patrones

de tamaño natural y mas de 400 de dibu. jo para bordados y labores á la agruja. 33 FIGURINES ILUMINADOS á lo aguado sobre cartulina bristol del mismo tamaño que el periódico.

Se suseribe en la Af́ENCIA CEN. TRAL DE PERIODICOS.

Ofleina de Inján, por \$ 6.ał año.

Fuente: El Correo de Costa Rica (23 de diciembre de 1888, p. 4).

Figura 7. Anuncio de La Moda Elegante en El anunciador costa-ricense

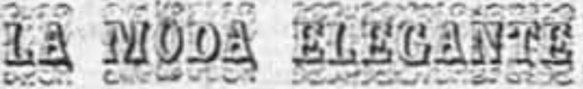

I L U S T A D A para 1891. SUBCRICION AL ANTO 15.00.

Fuente: El anunciador costa-ricense (16 de junio de 1895, p. 35). en Costa Rica, y es posible encontrar anuncios de estos figurines en periódicos costarricenses. Por ejemplo, El Correo de Costa Rica muestra un anuncio del periódico de modas La Estación: "Se suscribe en la Agencia Central de Periódicos, oficina de Luján, por $\$ 6$ al año" (fig. 6). Por su parte, $E l$ Anunciador Costa-ricense, publicado por la Librería Española en San José, ofrecía suscripciones a $L a$ Moda Elegante por \$15 (fig. 7). Estos precios son elevados si se toma en cuenta que, en los años 1890 y 1891, el salario mensual de un diputado era de 200 pesos, mientras que un profesor de secundaria ganaba 100 pesos; un maestro, 50 pesos; y un peón, 30 pesos (Vega Jiménez, 1998, p.12).

De este modo, puede afirmarse que estos figurines de moda llegaban al país y eran consumidos por un público de clase alta que podía utilizar la información para acercarse al gusto francés en la vestimenta. A fin de comprender el tipo de información que ofrecían los figurines de esta colección, la tabla 1 (ver página siguiente) detalla las características de estas publicaciones.

\section{Los figurines de moda y la formación del gusto en las élites costarricenses}

Las últimas décadas del siglo XIX en Costa Rica fueron marcadas por el proyecto político del liberalismo. El sistema económico costarricense se basaba en la agroexportación desde la década de 1840, lo cual había creado un poderoso grupo económico y político: la oligarquía cafetalera. Esta élite acumuló riqueza y se convirtió en el sostén del Estado, por lo que las políticas estatales reflejaron los intereses de ese grupo, que procuraba emular la cultura europea en muchos ámbitos, no solo en la política. Así, los procesos culturales considerados 
de "buen gusto" en Costa Rica fueron los que prefería la oligarquía. A su vez, este grupo emulaba los gustos europeos, especialmente los franceses, en temas como la arquitectura, el teatro, la música, la moda y la gastronomía. Este será el segmento social que de aquí en adelante se denominará "la élite" en Costa Rica.

\begin{tabular}{|c|c|c|c|}
\hline & La Estación & La Moda Elegante & $\begin{array}{c}\text { La Revista llustrada de } \\
\text { Nueva York }\end{array}$ \\
\hline Lugar de publicación & París & Madrid & Nueva York \\
\hline Periodicidad & 2 veces al mes & 4 veces al mes & 1 vez al mes \\
\hline Costos de suscripción & $\$ 6$ al año & \$15 al año & $\$ 3$ al año (en oro americano) \\
\hline Público meta & Femenino $^{7}$ & Femenino $^{8}$ & Femenino y masculino \\
\hline Temas & $\begin{array}{l}\text { Crónicas de moda } \\
\text { llustraciones de moda } \\
\text { Patrones para ropa y } \\
\text { accesorios } \\
\text { Explicaciones de los } \\
\text { patrones } \\
\text { Labores femeninas } 9 \\
\text { Ropa infantil }\end{array}$ & $\begin{array}{l}\text { Crónicas de moda } \\
\text { llustraciones de moda } \\
\text { Labores femeninas } \\
\text { Textos sobre prácticas socia- } \\
\text { les } \\
\text { Crónicas y novelas por entre- } \\
\text { gas } \\
\text { Correspondencia de lectoras } \\
\text { Anuncios comerciales }\end{array}$ & $\begin{array}{l}\text { Asuntos internacionales } \\
\text { Ciencias } \\
\text { Novelas por entregas } \\
\text { Noticias de Europa y EEUU } \\
\text { Temas de arte y música } \\
\text { Anuncios comerciales } \\
\text { Revista de modas ilustrada }\end{array}$ \\
\hline $\begin{array}{l}\text { Cantidad de ejemplares } \\
\text { en el acopio }\end{array}$ & 14 , entre 1889 y 1894 & 42, entre 1892 y 1896 & 12, año 1889 completo \\
\hline
\end{tabular}

Un aspecto igualmente importante en este período es el aporte de la industrialización para la diseminación de los objetos de consumo. La mejora en los transportes por barco y ferrocarril permitió la importación más rápida y eficiente de objetos de consumo, entre ellos los insumos necesarios para la producción textil nacional. Según Bauer, (2002) durante este período en Latinoamérica se importaron telas, prendas de vestir, alfileres, agujas, cortinas y los primeros zapatos

7 Esta revista se caracterizaba en su encabezado como un "periódico para señoras" ( $1^{\circ}$ de octubre de 1889, p. 145).

8 La Moda Elegante se describía como un "periódico especial de señoras y señoritas, indispensable en toda casa de familia" (6 de marzo de 1892, p. 97).

9 Las labores femeninas que se detallan en estas revistas pueden incluir pintura, repujado, bordado, tejido, elaboración de encajes, manualidades, juguetes, etc. 
producidos en serie. También, la imprenta resultó esencial para la publicación de periódicos en nuestro país, con sus consecuentes anuncios de objetos importados y de servicios de costura y sastrería; además, sirvió para la difusión de los gustos extranjeros gracias a los figurines de modas. Con la llegada de estas publicaciones, se logra que: "los hombres y las mujeres acaudalados no sólo se sintieran atraídos por los nuevos dictados de la moda que provenían del extranjero, sino, lo que es más importante, que aceptaran un patrón de estilos periódicamente cambiante" (Bauer, 2002, p. 197).

Las mejoras tecnológicas de la industrialización también fueron esenciales para acelerar el cambio en la confección de objetos de consumo. Así, un constante flujo de modas cambiantes alimentaba las páginas de los figurines de la época. Estas modas inestables requerían un constante esfuerzo por actualizar los usos y las costumbres de los consumidores para legitimar una posición social determinada. Es decir, cuanto más se aceleró la producción de la moda, tanto más rápidos fueron sus cambios, por lo que los consumidores esperaban información frecuente y actualizada que les permitiera orientar sus elecciones de consumo para denotar su estrato social. Costa Rica no fue ajena a este fenómeno, si bien las condiciones económicas del período con respecto a la importación de bienes no se comparaban con la aceleración sentida en Europa, aun así, la llegada de estos figurines de moda hace evidente que nuestro país no se podía sustraer de las corrientes de la moda francesa, ya un fenómeno mundial.

Precisamente, un aspecto que destaca del análisis de los figurines del acopio es su insistencia en declarar una relación con las modas francesas. Para comprender la relevancia de estas afirmaciones, es necesario describir brevemente, la situación de la moda francesa en el siglo XIX. Según lo detalla Boucher (1997), la influencia del gusto francés se extendió por el mundo desde el siglo XVIII, debido a razones culturales, como el prestigio de Versalles, la adopción del francés como lingua franca en los círculos cultos. y la aparición de revistas de moda francesas después de la década de 1760 (pp. 318 y 319).

Durante el siglo XIX, la preponderancia francesa continuó, apoyada por los desarrollos tecnológicos de la Revolución Industrial. En el tercio final del siglo XIX, las modas francesas se extendieron por todo el mundo, incluidas África, Asia y América:

La orientación cultural de las élites latinoamericanas se dirigió al Norte de Europa y, más tarde, a los Estados Unidos. Aunque fuesen nacionalistas políticamente, las élites se preocupaban por diferenciarse de la masa de sus compatriotas y por demostrar sus conexiones con el mundo de la alta cultura en París y Londres (Ross, 2008, p. 71).

Al llegar a Costa Rica, los figurines del acopio representaban un elemento que contribuía a difundir los gustos europeos en nuestro país. Si bien no todos se editaban en la capital francesa, los textos que acompañan los grabados de moda con frecuencia mencionan la 
relevancia del gusto francés en el campo de la moda. El asociarse directamente con las modas francesas, sus usos y costumbres, se utilizaba como un recurso que alentaba a las lectoras a seguir los consejos de una determinada revista de modas. Así, se suponía que el habitus de las clases altas parisienses era el que las élites de otros países querrían emular: sus elecciones de consumo en la moda serían consideradas las de mejor gusto.

El hecho de que una revista insistiera en que sus grabados y sus textos reproducían fielmente lo visto entre las mujeres elegantes de la capital francesa, se convertía en una especie de garantía para las lectoras de centros urbanos alejados, quienes podrían seguir estas pautas y evitar la vergüenza que produce el utilizar prendas atrasadas. La revista La Estación reafirma estas ideas en sus textos: "Además, si nuestras lectoras siguen los patrones é indicaciones de nuestro periódico, pueden estar seguras de vestirse con arreglo á la última moda y sobre todo con distinción, lo cual es de suma importancia" (16 de noviembre de 1894, p. 169).

Asimismo, en algunos textos de los figurines se hacen referencias a la supremacía del gusto francés comparado con los de otros países: "Puede decirse que, en Francia, y particularmente en París, la mujer sabe calzarse con elegancia y comodidad. Fuera de aquí no dan importancia á la ligereza y buena hechura ... Quizás eso depende del empedrado de las calles" (La Estación, 16 de setiembre de 1894, p. 137). En este caso particular, se hace una comparación que llega a incluir la calidad urbanística de otras ciudades: el texto implica que la mujer francesa se calza con zapatos elegantes y ligeros, los cuales se desenvuelven correctamente en calles empedradas con cuidado. Entonces, esto no es posible en ciudades cuyo pavimento es de inferior calidad. Así, las elecciones en la moda dependen incluso de poseer espacios urbanos correctamente desarrollados para mostrar las prendas y los accesorios finos y de buena calidad, sin que estos se dañen o causen que quien los porta se tropiece o sufra un accidente similar.

Un aspecto de especial importancia con respecto a los espacios urbanos es el surgimiento de las tiendas por departamentos en la Europa del siglo XIX. Estos establecimientos atraían a sus clientes con vitrinas lujosas y brindaban un espacio elegantemente decorado donde las mujeres podían pasear sin chaperonas (Groom, 2012, p. 172). En estas grandes tiendas podían adquirirse objetos de moda, vestimenta e insumos para coser y decorar las prendas. En La Moda Elegante del 30 de marzo de 1892 (fig. 8) aparece un

Figura 8. Anuncio de Au Bon Marché, en La Moda Elegante

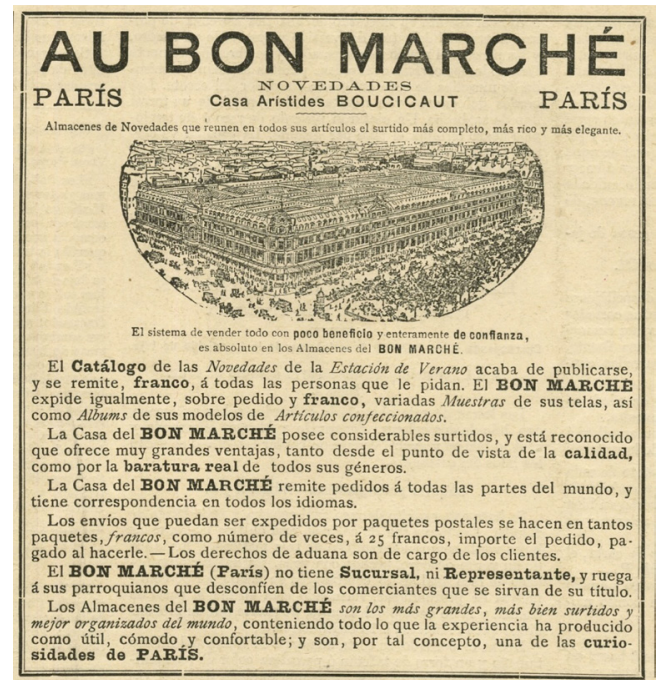

Fuente: La Moda Elegante (30 de marzo de 1892, p. 144). 
anuncio de una de las tiendas por departamentos más conocidas de París, Au Bon Marché. En este anuncio se ofrece el envío del catálogo de verano de la tienda, así como la posibilidad de solicitar muestras de telas y catálogos de artículos ya confeccionados. Se enfatiza que estos productos se remiten a todas partes del mundo y que la correspondencia se ofrece en varios idiomas, no solo en francés. Para darse una idea de la importancia del comercio internacional con respecto al consumo interno francés "en 1894, solamente para la temporada de invierno, la tienda envió 1.500 .000 de catálogos, de los cuales 740.000 estaban destinados a las provincias [francesas] y 260.000 se remitían al extranjero" (Miller, 1981, pp. 61-62).

Se conservan registros de que $\mathrm{Au}$ Bon Marché mandaba por correo catálogos y productos a Centroamérica. Por ejemplo, para el período fiscal de 1902-1903, este almacén envió a nuestra región paquetes valorados en 167.702 francos, no muy alejado de los 197.807 francos en envíos a España (Miller, 1981, p. 63). Existen evidencias de que en Costa Rica se podían adquirir productos de grandes almacenes franceses, como lo rescata Vega Jiménez (1998), quien reproduce un aviso aparecido en el diario El Heraldo de Costa Rica, en enero de 1898, en el cual se mencionan el catálogo de ropa blanca que publica el almacén parisiense Au Printemps. Quien escribiera a una dirección en París, podría recibir gratis el susodicho catálogo, que contenía muestras y detalles de "los artículos de telas hilo, algodón blanco, lencería, ajuares, canastilla, mantelería encajes, géneros de punto, cortinas etc." (p. 8). Adicionalmente, los paquetes valorados en más de 50 francos se expedían libres de franqueo hacia nuestro país. Todos estos son indicios de las maneras en las que los productos franceses se difundían por el mundo, llevando consigo los conceptos sobre la preponderancia del gusto francés en la moda. Los anuncios en los figurines ponían a las lectoras en contacto con este tipo de proveedores, cuyo nexo con París se tornaba esencial como "garantía" de buen gusto.

\section{Análisis de fotografías y figurines}

Al revisar los periódicos costarricenses de fines del siglo XIX se determina que en la prensa se encuentran avisos comerciales y breves artículos que detallan la relación de la sociedad costarricense con la moda. Sin embargo, no se pueden encontrar descripciones ni ilustraciones específicas sobre prendas femeninas. Esto es un punto importante: las mujeres de clase alta necesitaban encontrar esta información visual en alguna fuente, de tal forma que, se mantuvieran al tanto de los cambios suscitados en la moda parisiense. Las fuentes más comunes de esta información son los figurines de modas, ya que podían imprimirse masivamente y distribuirse con facilidad a los suscriptores en muchos países, como anteriormente se demostró. En Costa Rica no existía una producción propia de revistas sobre moda a finales del siglo XIX, por lo cual la posibilidad de suscribirse a revistas extranjeras era esencial. 
En los múltiples avisos que publican las importadoras, las tiendas y los fabricantes de ropa costarricenses se pueden encontrar listados géneros de distintos precios, accesorios, pasamanerías y decoraciones, así como la oferta para confeccionar prendas con estos insumos. Aun así, falta completar el panorama que se relaciona con los estilos en boga: ¿cómo podían saber las clientes cuál era la forma "correcta" de confeccionar las prendas o combinar las telas? Esta información debía proceder de los figurines, de sus breves textos y detalladas imágenes.

Con el fin de comprobar la influencia visual del contenido de los figurines sobre los gustos de las élites en nuestro país, se realizó un análisis de la vestimenta que se muestra en los retratos fotográficos de las últimas décadas del siglo XIX. El acopio del Museo Nacional de Costa Rica ${ }^{7}$ posee una cantidad apreciable de retratos de este tipo, de los cuales se seleccionaron tres, debido a que se aprecian en ellos, con mucho detalle, las características del vestuario de las mujeres de clase alta. Estos retratos se compararon con las ilustraciones de los figurines, para detectar similitudes en los cortes, siluetas, materiales, adornos y demás detalles de la ropa.

El retrato de la señora Tinoco (fig. 9) muestra a una mujer adulta, quien lleva un vestido largo de color oscuro, de tela de raso guarnecida con bordados florales y arabescos. El corpiño simula una chaqueta, con amplio escote en $V$ hasta la cintura, cuyos bordes están decorados con aplicaciones de encaje y pedrería con motivos florales. Las mangas son dobles: las externas llegan hasta el codo, abiertas y decoradas con un gran lazo de cinta; las mangas internas son de tela de rayas, y llegan hasta la muñeca. El corpiño se completa con una pechera que cubre el frente, de cuello muy alto y decorado con una chorrera de guipure blanco. La falda roza el suelo y se extiende hacia atrás en una cola medianamente larga. La parte delantera muestra dos columnas de alforzas y bordados florales. Alrededor del bajo de la falda se aplicaron generosamente volantes y cintas.

Figura 9. Fotografía de la señora de Tinoco.

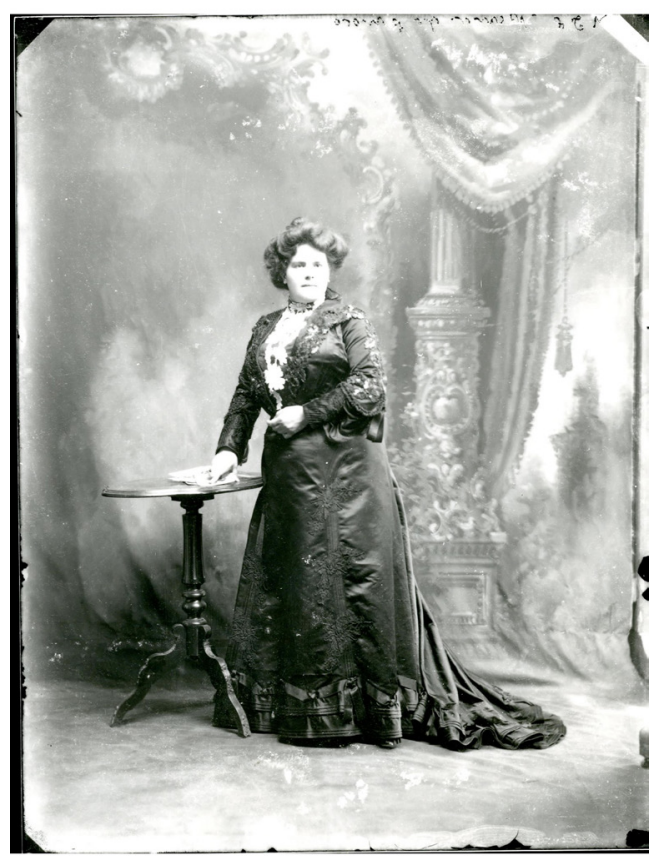

Fuente: Museo Nacional de Costa Rica, ( $N^{\circ}$ de registro 28887)

7 De este acopio se revisaron fotografías provenientes del estudio de Rudd y Paynter, en San José, sin fecha; del álbum Vistas de Costa Rica, de H. G. Morgan, de 1892; del Libro Azul, de 1916; y otras de formato grande, sin fecha ni autor. Por razones de espacio, se escogieron tres fotos en buen estado de conservación y excelente nivel de detalle. 
Se puede encontrar un modelo similar en $\mathrm{La}$ Estación (fig. 10). En el texto que acompaña la ilustración, se aconseja el uso de colas pequeñas para complementar los trajes algo lujosos. Es interesante notar que este vestido se recomienda para las señoras mayores, debido a sus colores oscuros, telas más pesadas y aspecto más modesto en los escotes. La postura de la señora de Tinoco y del figurín son muy similares y ayuda a lucir las grandes cantidades de tela en las colas y los ornamentos lujosos de los trajes. En general, los figurines enfatizan en la importancia visual de las colas de las faldas al extenderlas hacia el frente. La cola del vestido en la fotografía fue dispuesta de una manera muy similar, de tal modo que sea fácilmente legible el grado de lujo de este vestido.

Además, un vestido tan opulento como el que luce la señora de Tinoco ayuda a reforzar visualmente su pertenencia a la élite. El imponente volumen de su falda, los complejos ornamentos de su traje y la postura recta conseguida con el uso del corsé son parte de los elementos visuales que se asocian con las mujeres de clase alta. Al analizar el peso de los materiales que ella utiliza sobre su cuerpo ${ }^{8}$, se llega a la conclusión de que es necesaria una educación muy específica que familiarice al cuerpo con la necesidad de moverse en los espacios con una larga y pesada cola que se extiende detrás de la figura. Esta "familiaridad" con las telas caras, las colas largas y las mangas decoradas es una característica del análisis bourdesiano del habitus de clase de las élites del siglo XIX: una mujer como la señora de Tinoco podría utilizar la información contenida en los figurines para asimilar las maneras "correctas" de vestir, de posar para un retrato y de interactuar con el mobiliario para ofrecer el aspecto "digno" de su clase social.

De igual modo, los figurines permitían a las mujeres de la élite orientar sus elecciones de consumo para denotar su jerarquía social "correctamente"; es decir, seleccionando objetos que

8 Se conoce que, a fines del siglo XIX, la Rational Dress Association de Inglaterra recomendaba que la ropa interior de las mujeres no llegase a pesar más de $3.2 \mathrm{~kg}$ (Rose, 2014, p. 83). Esto no incluye el peso de sus prendas exteriores ni accesorios.

ESCENA. Revista de las artes, 2017, Volumen 77, Número 1, págs. 4-30 ISSN 1409-2522 
se valorasen en sociedad como de "buen gusto". Con estas elecciones de consumo, que forman parte del habitus de clase, se legitima el lugar que una persona ocupa en sociedad. En la Costa Rica finisecular se buscaba utilizar este habitus de clase para sostener simbólicamente la élite oligarca del país: sus objetos de consumo debían poder leerse como los que pertenecían a las clases altas de todo el orbe. Esto los legitimaba dentro y fuera de nuestro país. Así, los figurines enseñan cuáles objetos se valoran como "apropiados" dentro del habitus elitista. Además de mostrar trajes completos, los figurines del acopio enfatizan la necesidad de cuidar meticulosamente los pequeños detalles de cada atuendo:

Un traje, por bonito que sea, no puede considerársele como completado, si la señora que le lleva ha descuidado esos casi nada que son como si dijéramos la quinta esencia del gusto. Importa pués, que de esos casi nada se haga una buena elección evitando con precaución la vulgaridad (La Estación, 16 de mayo de 1889, p. 73).

Seguido a esa afirmación, se menciona que tales detalles son cintas, flores, pañuelos, pecheras, chorreras de encaje, paraguas, sombreros y sombrillas de tul. El texto continúa con la recomendación de que la mujer elija accesorios caros por encima de los baratos. También que renuncie del todo a ellos si no puede costearse, por ejemplo, las chorreras de encaje verdadero de Valenciennes, en vez de las hechas con encaje de imitación.

Lo anterior se relaciona muy directamente con los conceptos de gusto y de proceso civilizador que fundamentan este artículo. En primer lugar, la revista afirma que la mujer no debe descuidar pequeños detalles en su vestimenta, los cuales parecen representar la "verdadera" noción del buen gusto. Es decir, si la dama ya ha seguido los consejos de la revista con respecto a las piezas de su atuendo, continúa el proceso de formar su gusto, ahora enfocándose en los pormenores de decorar y complementar su atuendo. Estos podrían representar una dificultad para quienes no están correctamente socializadas con respecto a los dictados del buen gusto, por lo que es necesario que la revista explique cuáles elementos deben elegirse y por qué.

Se espera que una mujer se vista de manera elegante y de "buen tono", pero esto necesariamente implica un balance entre la ostentación llamativa del lujo y la pobreza en los detalles. Se espera que una mujer se eduque con respecto a cuáles prendas, accesorios y materiales son suficientemente caros para ser considerados de buen gusto, pero no tan onerosos que parezcan una ostentación vulgar. Esta complicada aritmética social era parte esencial de la formación del gusto que se realizaba mediante los figurines de moda. Una mujer que viviese lejos de Francia podía confiar en que estas revistas le traían los estilos más "apropiados" para su clase social, además de ayudarla a navegar los complejos detalles de cómo debía orientar su consumo. Para emular el "buen gusto" que se pregonaba en estas revistas, las suscriptoras encontraban grabados, ilustraciones y anuncios con la información necesaria, así como los proveedores que podían ofrecer estos objetos, sancionados por el "buen tono" parisiense. 
Figura 11. Fotografía de dos señoritas, Rudd y Paynter

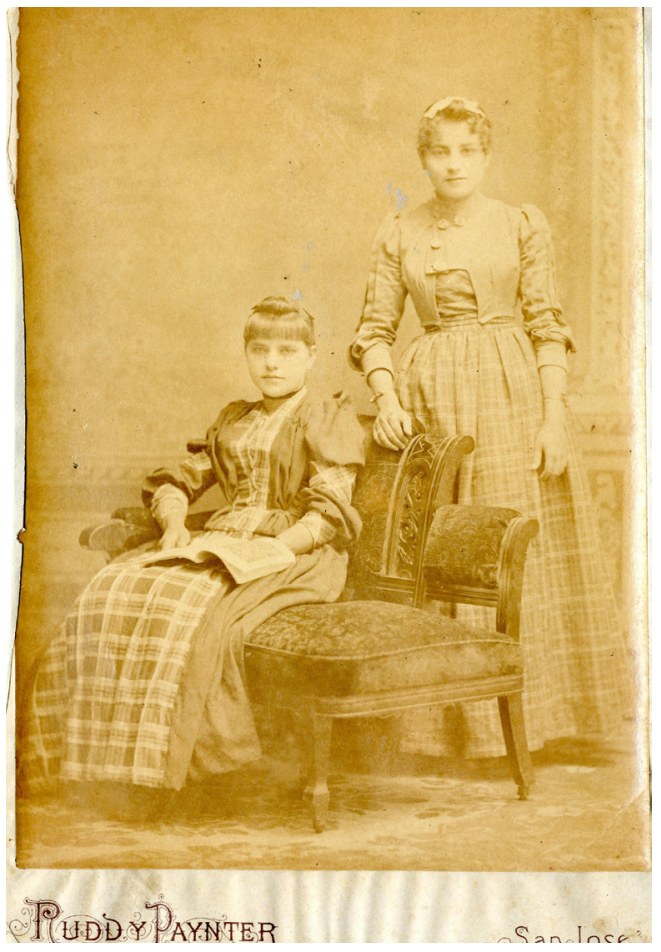

Fuente: Museo Nacional de Costa Rica, (No de registro 1006).
Figura 12. Blusa de tejido jersey para viaje, $L a$ Estación

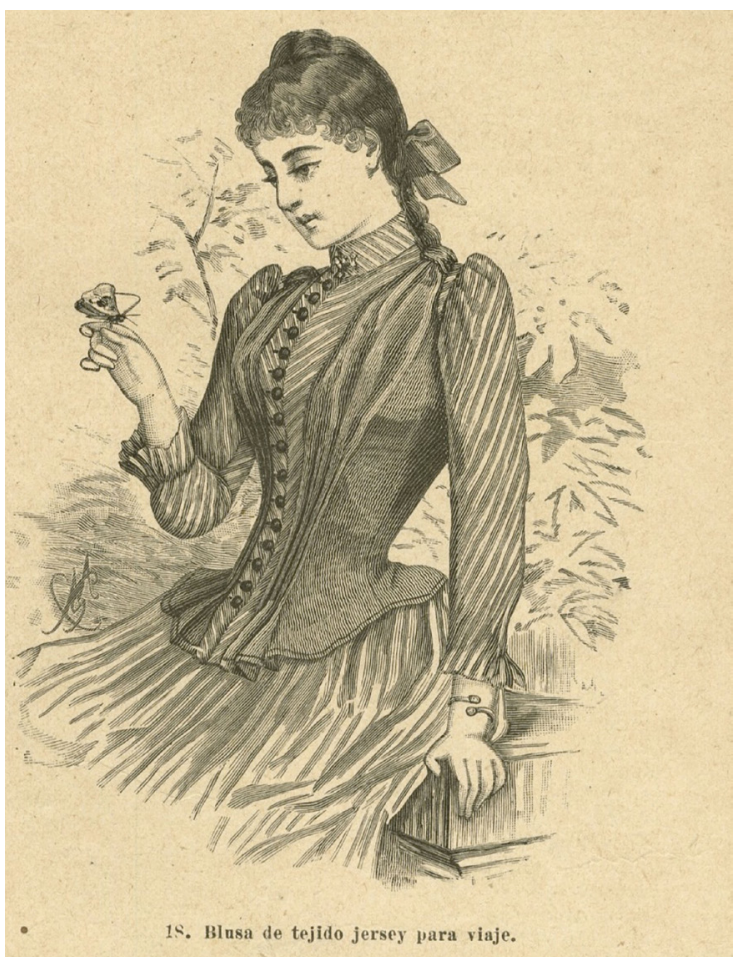

Fuente: La Estación (16 de junio de 1889, p. 91).

En la figura 11 aparecen dos señoritas, retratadas en el estudio de Rudd y Paynter, en San José. Ambas mujeres llevan vestidos largos que requieren del uso de corsés, hechos en telas de cuadros combinadas con telas lisas para generar contraste. Las mangas tienen mucho volumen en el hombro, y se ajustan bajo el codo. Los trajes llevan cuellos altos, corpiños muy acinturados, y faldas con tablas o fruncidos para dar volumen.

Un tipo de corpiño o blusa similar al que lleva la joven sentada aparece en La Estación (fig. 12). La mezcla de tejidos lisos con otros de rayas o cuadros es un estilo muy en boga en las décadas finales del siglo XIX, aunque la similitud entre estas imágenes abarca también la forma de sentarse. La joven retratada en la fotografía utiliza necesariamente un corsé, según se explicará más adelante, lo cual obliga a su cuerpo a tomar una postura muy similar a la del figurín: busto levantado, espalda recta, torso impulsado hacia delante, y cintura marcada. 
Los vestidos de cuadros aparecen con frecuencia en los figurines del acopio. Por ejemplo, La Moda Elegante muestra un vestido de calle de tela escocesa de cuadros, combinada con tela lisa de paño en un color similar (fig. 13). Las mangas jamón que muestran los vestidos de la fotografía aparecieron a partir de los primeros años de la década de 1890. Su característica principal era un aumento del volumen en el hombro, el cual se ajustaba al llegar al codo o la muñeca. Este cambio en la silueta de las mangas permitía distinguir visualmente los trajes más a la moda de aquellos que habían quedado rezagados según avanzaba el decenio.

El análisis de los figurines del acopio permite entrever la forma en la que se difundían las ideas que formaban el gusto de sus lectoras. Es de suma importancia notar que los cambios en la vestimenta, en la forma de llevar las ropas y de comportarse en sociedad requieren una educación constante para mantenerse al tanto de los nuevos usos y no encontrarse fuera de los comportamientos "civilizados". Los figurines ayudan a diseminar los usos "correctos", aunque la misma periodicidad de las publicaciones implica que estas costumbres son cambiantes y necesitan un refrescamiento frecuente.

Todo lo anterior pertenece al concepto de proceso civilizador vinculado a los procesos graduales y constantes que permiten el cambio en las costumbres de una sociedad. Las elecciones acerca del consumo de moda son parte de esto: el abandono de ciertas prendas, estilos, colores y siluetas está aparejado con la idea de que se han tornado anticuados, y que seguir utilizándolos puede llevar al ridículo o al escarnio social. Los figurines de moda prometían mantener a sus lectoras avisadas de estas variaciones, de tal modo que evitaran las sanciones sociales.

La figura 14 muestra a un par de señoras ataviadas de manera muy distinta. La mujer de la izquierda lleva un traje tipo "campesina" elegante: una blusa blanca suelta y de manga corta, con un gran volante de encaje sobre el pecho y una falda voluminosa con un gran vuelo plisado y decorado con un listón de terciopelo en el bajo. Este tipo de traje no aparece en ninguna ilustración de los figurines del acopio. Pareciera ser una variación hecha con telas más caras y 
Figura 14. Dos mujeres, Rudd y Paynter

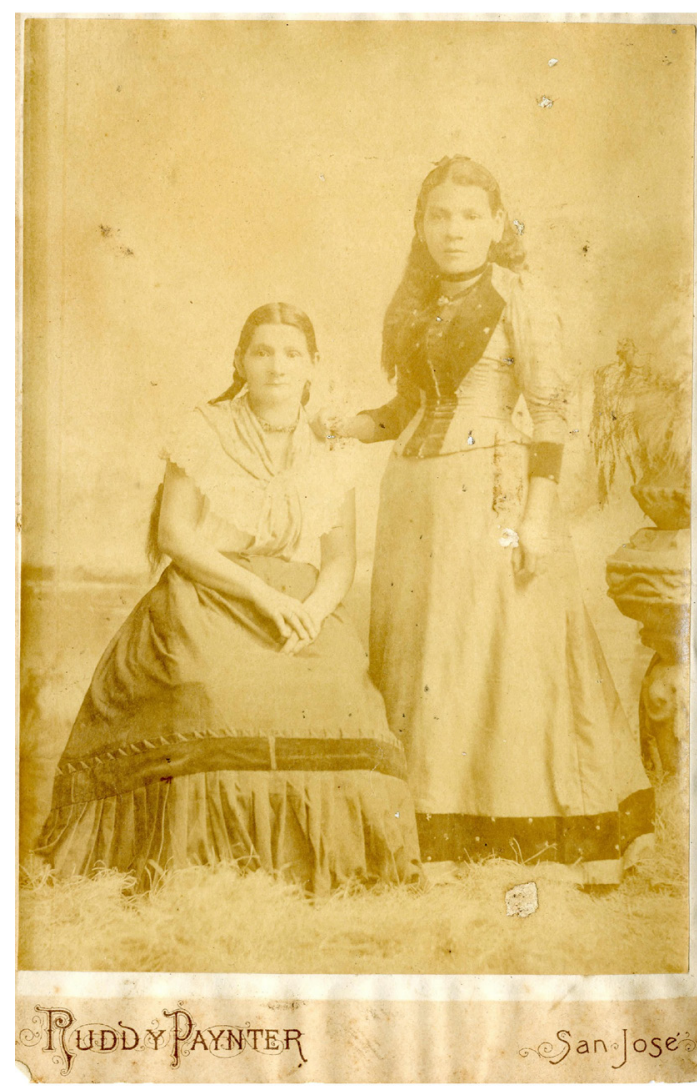

Fuente: Museo Nacional de Costa Rica, (No de registro 977)

de mejor calidad de las ropas que llevan las campesinas costarricenses. Posiblemente, la mujer utiliza una crinolina de aros para sostener el volumen de la enagua, aunque el uso de las crinolinas de aros había pasado de moda en Francia a fines de la década de 1860 , por lo cual este tipo de estructuras internas no aparecen en las ilustraciones de los figurines. Las mangas tan cortas tampoco eran usuales en los trajes de día de estilo francés, en los que se tendía a cubrir casi completamente los brazos. Ameritan una investigación posterior las grandes diferencias entre estos trajes, que se reconocen como variaciones del "traje típico" costarricense y las notables influencias de la moda francesa, como el traje de la mujer a la derecha de esta foto.

Por su parte, la mujer joven lleva un traje de dos piezas con falda larga hasta el suelo y corpiño tipo chaqueta, muy entallado. El cuello y los puños están confeccionados en un material contrastante y luce mangas jamón con volumen en los hombros. $\mathrm{Su}$ cuerpo se nota definitivamente moldeado por el corsé. Los figurines de modas presentan evidencias visuales de la feminidad ideal del período. Las mujeres que se representan en estas imágenes se encuentran encorsetadas, con el típico corsé de finales del siglo XIX. Esta prenda interior proporcionaba un aspecto característico: cintura muy marcada, busto amplio, caderas llenas y el torso empujado ligeramente hacia delante. En sí, los corsés admiten lecturas muy complejas ${ }^{9}$ que se relacionan con la manera adecuada de presentar el atractivo sexual de las mujeres en una sociedad tan reprimida como la de finales del siglo XIX.

El uso del corsé era obligatorio en las mujeres de clase alta, quienes debían llevar esta prenda en todo momento. La figura 15 muestra un corsé, descrito así: "Una señora bien adecuada no está nunca sin corsé, á no ser que esté enferma. ... Se pondrán botones para sostener el pantalón y las enaguas [sic]" (La Estación, $1^{\circ}$ de octubre de 1889, p.146). La obligación de encorsetarse aparece con frecuencia en los figurines. Se insiste en que una mujer decente nunca

9 Se puede consultar el completo análisis sobre el corsé escrito por Valerie Steele en The Corset: A Cultural History (Yale University Press, 2007). 
Figura 15. Corsé, La Estación

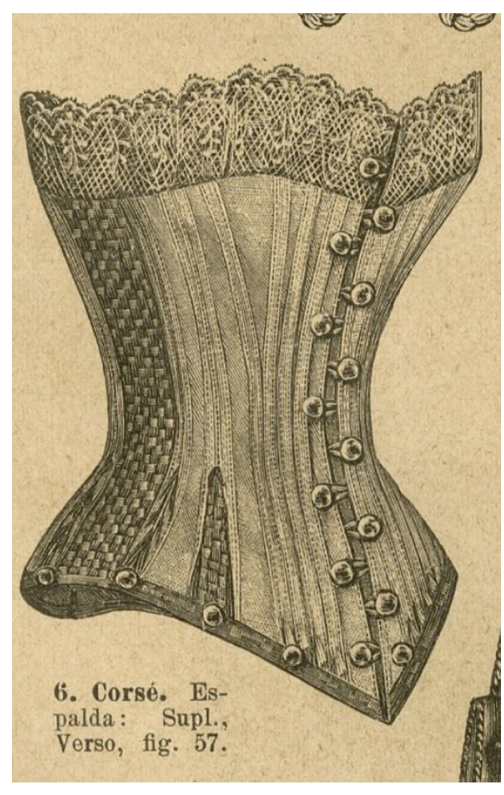

Fuente: La Estación, (1 de octubre de 1889 , p. 146).

Figura 16. Enagua de surah, La Moda Elegante

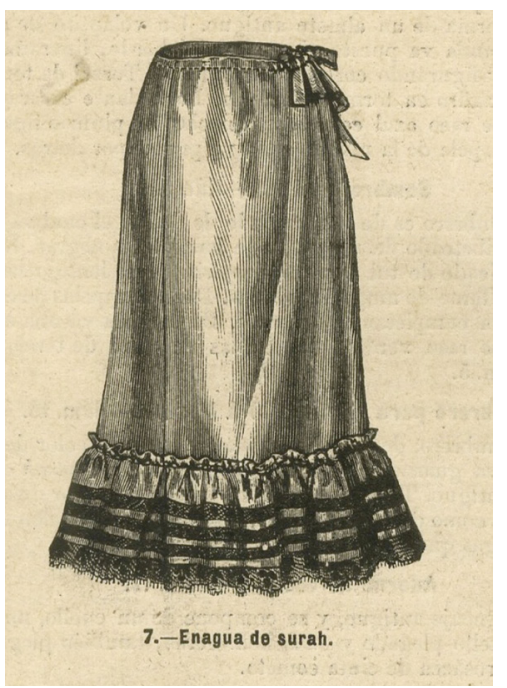

Fuente: La Moda Elegante (s.f., p. 231). se presenta sin haber moldeado firmemente su cuerpo con esta prenda interior. De esta manera, la utilización del corsé por las mujeres costarricenses denota su conexión con los ideales femeninos "afrancesados": se utiliza el recurso visual del cuerpo moldeado por el corsé para evidenciar la pertenencia a la clase de mujeres "decentes" y "de buena familia" que leen y asimilan los contenidos de los figurines.

Los corsés no eran la única prenda interior que llevaban las mujeres de clase alta. En los figurines aparecen prendas interiores como cubrecorsés, camisas interiores, pantaletas y enaguas internas (fig. 16). La profusión de adornos que requería cada una de ellas aumentaba la complejidad, el peso y el precio del ajuar femenino:

Esta enagua, hecha de surah color de paja, va guarnecida de un volante dentado de la misma tela, de 17 centímetros de alto, y de un volante de encaje negro de 15 centímetros. Se cosen sobre este volante tres tiras estrechas de raso maravilloso, y se guarnece su borde superior con una tira de la misma tela, que se frunce varias veces y se cose sobre la enagua (La Moda Elegante, s.f., p. 231).

Precisamente, la complejidad de las prendas interiores y exteriores femeninas era una forma de establecer las distinciones de clase: sólo las élites podían permitirse gastar el dinero necesario para completar un guardarropa como el descrito en los figurines. Además del gasto en comprar o mandar a hacer la ropa, era necesario gastar tiempo y dinero en su cuidado: en lavar, planchar, almidonar y reparar las prendas. Las mujeres que seguían los dictados de la moda francesa de élite no podían realizar labores físicas extenuantes debido a la rigidez de los corsés; el volumen, el largo y la delicadeza de sus prendas exteriores. Por todas estas razones, se considera que el consumo de prendas de vestir contribuye a generar y mantener las diferencias entre las clases sociales.

El consumo de moda en Costa Rica a fines del siglo XIX estuvo regido por varios aspectos importantes, especialmente 
por la diferenciación debida a las clases sociales. Según Vega Jiménez (1991), el costo del atuendo de un caballero elegante hacia mediados del siglo XIX en nuestro país era muy elevado e inaccesible para un jornalero de clase baja (quien percibía un salario mensual de entre 15 a 18 pesos en 1858):

Un pantalón de casimir de calidad superior costaba 12 pesos en 1858, y unas botas de charol 8 pesos. Si consideramos que un sombrero fino tenía un costo de 7 pesos y 3 reales y una camisa de lino 2 pesos, sin tener en cuenta las camisetas, las medias ni los calzoncillos, el costo de una mudada estaba cercano a los 30 pesos (p. 63).

Por su parte, las damas de clase alta "tenían para elegir entre listones, abalorios, aretes, guantes y medias como accesorios a sus vestidos, además de perfumes, colonias y polvos de arroz. Para confeccionar los trajes, los almacenes ofrecían las más variadas telas: "algodones y linos, sedas provenientes de París, Londres y China” (Vega Jiménez, 1991, p. 65). Como parte de sus importaciones, Costa Rica recibía telas y pasamanerías provenientes de la capital francesa. Así puede apreciarse en los anuncios publicados por Elisa M. de Bellard (fig. 17) y por la tienda La Villa de París (fig. 18). Estos objetos permitían seguir los dictados de los figurines de moda, los cuales guiaban el consumo de las mujeres de la élite en nuestro país.

Figura 17. Anuncio de productos importados de París, en El Heraldo

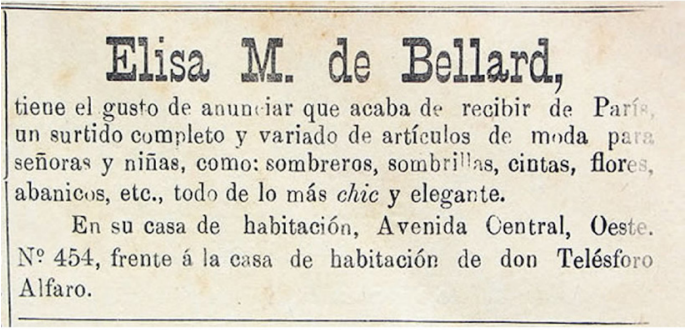

Fuente: El Heraldo, (8 de octubre de 1897, p. 3).
Figura 18. Anuncio de La Villa de París, La República

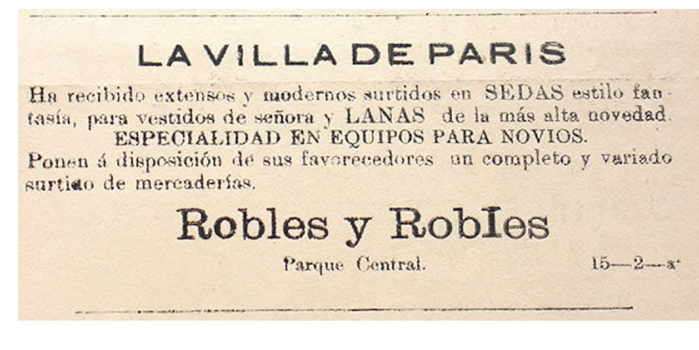

Fuente: La República, (8 de agosto de 1897, p. 3).

Las sedas de fantasía, como las que anunciaba La Villa de París, eran bastante caras, tanto por su producción laboriosa como por sus acabados muy opulentos. Adicionalmente, los trajes de las damas de la élite podían requerir grandes cantidades de tela: en el número del 16 de marzo de 1889 de La Estación se mencionan trajes con sobrefaldas de 3 metros de vuelo y $125 \mathrm{~cm}$ de largo. Si se toman en cuenta las recomendaciones de los figurines con respecto a las generosas cantidades de tela de cada atuendo, así como los requerimientos de pasamanerías para adornar los vestidos y sombreros, así como la cantidad de accesorios necesarios para completar el atuendo, es posible afirmar que este tipo de trajes se encontraba muy lejos de lo 
que una persona de clase trabajadora podía costearse: "la diferenciación social es clara. Los vestidos de las 'damas de la sociedad' tienen costos inalcanzables para los sectores populares de la población" (Vega Jiménez, 1998, p. 25).

Por el contrario, la vestimenta de los campesinos costarricenses era sencilla. Por ejemplo, un hombre utilizaba pantalones de dril o mezclilla, faja de cuero y camiseta de manta; para los domingos, camisa de lienzo. Los zapatos eran poco usados en este grupo social. Por su parte, las mujeres llevaban enaguas de zaraza, camisas de gola, fustanes almidonados y rebozos para los domingos (Vega Jiménez, 1998, pp. 5-7). El mercado costarricense ofrecía prendas de costos accesibles para las clases trabajadoras: por ejemplo, zapatos de piel de becerro por 2 pesos y pantalones de calidad inferior por 6 pesos, mientras que una vara de zaraza se obtenía por un real.

Los sombreros también sirven para diferenciar las clases sociales, especialmente en una época en la que se consideraba esta prenda como absolutamente imprescindible. Los precios de los sombreros en la tienda de José Esquivel podían estar entre los 2.50 y los 30 pesos. Las mujeres de clase alta los usaban, junto con las sombrillas decoradas, para protegerse del Sol. Mientras que las campesinas usaban sencillos sombreros de paja o de pita para viajes largos o trabajar en fincas (Vega Jiménez, 1998, p. 6).

Un aspecto importante para la difusión de las ideas que aparecían en los figurines del acopio era su posible utilización como referencia para las costureras en Costa Rica. Los figurines contenían patrones destinados a realizar las prendas y las labores que se mostraban en cada edición. Por ejemplo, La Estación mencionaba:

Nuestros modelos complicados, lo mismo que los informes ultraelegantes que publicamos, van dirigidos, más que á las señoras, á las modistas de vestidos y sombreros, que hallarán siempre en nosotros un apoyo y consejo desinteresados, basados en la mucha experiencia que llevamos adquirida. Al lado de estos modelos, destinados á las señoras del oficio, las señoras particulares y las señoritas hallarán, en nuestras pájinas, infinidad de modelos de vestidos, trajes y abrigos, fáciles de ejecutar una misma y á veces sumamente distinguidos [sic] (16 de marzo de 1889, p. 41).

De este modo, las costureras podían utilizar las imágenes de los figurines para ofrecer diseños novedosos a sus clientes, en especial para confeccionar vestidos complejos, como los trajes de baile o de novia. En un aviso publicado en La República (fig. 19), una costurera se pone a disposición de su clientela para la confección de este tipo de vestidos e incluso se compromete a conseguir los materiales necesarios. Así, es evidente que en nuestro país se podían conseguir telas de calidad suficiente para realizar vestidos lujosos y también cotidianos. Según Vega Jiménez, entre las importaciones textiles a Costa Rica el 91\% correspondían a algodones, 
mientras que el resto eran lanas, linos, yute y sedas. Se importaba menor cantidad de prendas terminadas, ya que se prefería comprar las telas y los insumos empleados en fabricar los trajes a la medida, tanto en las clases altas como en las bajas (1991, p. 65). Naturalmente, esto favorecía a la industria de la costura y a la sastrería nacionales, que necesitarían referentes de los trajes de moda para confeccionar vestidos a las clases altas. Es posible encontrar anuncios de los insumos necesarios para la costura, además de avisos sobre máquinas de coser (fig. 20).

Figura 19. Anuncio de la costurera Rafaela Cantillo, en La República

\section{A VISO}

Tengo el gusto de participar á mi numerosa clieat la y demás señoras, que el 23 del corriente abro nue vamente mi taller de costura en la calle i6 Norte, 365, casa de doña Gertrudis Artavia. Me comprom to hacer toda clase de obras que se me encarguen, com enaguas, vestidos de calle, de baile ó de novia ofrecién doles á las personas que me solicitan puntualidad y buen trabajo.

Tambiên me hago cargo de poner los materiales necesarios.

San José, 14 de agosto de 1897 . Rafacla Cantillo de Solano.

Fuente: La República (29 de agosto de 1897, p. 3).
Figura 20. Anuncio de de máquinas de coser en la tienda Uribe y Batalla, en El Anunciador Costarricense

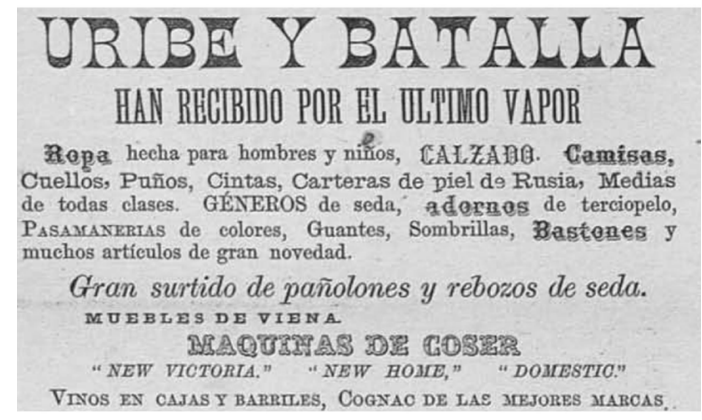

Fuente: El Anunciador Costa-ricense, $\left(1^{\circ} \mathrm{de}\right.$ setiembre de 1889 , p. 4).

Tomando en cuenta que los figurines podían ser usados por las costureras de diversos países, es notable la ausencia de recomendaciones para adaptar el atuendo parisiense a otras latitudes y a otros climas. De las tres publicaciones que conforman el acopio, únicamente $L a$ Revista Ilustrada de Nueva York hace un par de breves menciones a cómo adecuar las modas europeas a los países americanos:

Ya que de sombreros hablamos, ocúrresenos dar en nuestro grabado $\mathrm{n}^{\circ} 3$ la muestra de uno precioso, muy propio para usarse en los países del trópico. ... En nuestra América abundan las plumas vistosas y regias y, por consiguiente, el material tiene que contribuir al mayor brillo y riqueza del sombrero cuya descripción hacemos (diciembre de 1889, pp. 21-22).

En el mismo número se ofrece, como otra adaptación al clima tropical, la posibilidad de reemplazar los bordes de piel de un traje de calle para señoritas, con galones o bordados de seda o abalorios, de tal modo que, el traje sea menos caluroso. Es notable que estas recomendaciones no alteran la forma de los vestidos, ni sus siluetas, ni cantidad de prendas o materiales, más bien se enfocan en algunos pequeños cambios, como la forma del sombrero y sus decoraciones, o los ornamentos de un traje. Así, es posible vislumbrar cómo se esperaba que las damas copiaran las prendas francesas sin hacer mayores cambios en las estructuras generales. 
Según los figurines, las únicas variaciones aceptables correspondían al tipo de vestidos y a los materiales estacionales (es decir, a los guardarropas de verano e invierno), los que cambiaban de acuerdo con las estaciones del hemisferio norte; por tanto, se encontraban desfasadas del clima de América Latina.

\section{Conclusiones}

Al finalizar esta investigación, es posible confirmar la importancia de este acopio de figurines para entender el panorama de la moda en las clases altas de la Costa Rica de fines del siglo XIX. Se comprobó que estas revistas llegaban a nuestro país mediante suscripciones, por lo que la información contenida pudo diseminarse. Esto es esencial dentro del proceso civilizador de las costumbres y los gustos de las élites, un proceso que necesita la modificación de las conductas en la búsqueda de asociarse con un mayor grado de "civilización". Así, los figurines de modas ayudaron a las consumidoras a orientar sus elecciones de compra para escoger los objetos que se ajustaran al "buen gusto" francés. Por lo tanto, la información allí contenida podría ser de utilidad para las damas costarricenses que viajasen al exterior o que encargaran sus prendas de fabricantes franceses, pero también para aquellas que compraran productos importados a Costa Rica en los almacenes y tiendas del país. De ese modo, los figurines del acopio funcionaron como árbitros de lo elegante en lugares alejados de Europa, continuando el proceso de civilizar las costumbres y de formar el gusto de los compradores. La persistencia de los figurines en asociarse con la moda francesa ayudaba a su vez a difundir y a afirmar el criterio de que Francia era el centro del buen gusto.

En Latinoamérica es posible demostrar la existencia de un consumo diferenciado por clases sociales, el cual se expresa mediante las elecciones que sugieren los figurines de modas. Así, el consumo de bienes (y de imágenes) provenientes del extranjero distinguía a las élites de la masa campesina o aindiada: el contraste de las prendas caras y foráneas con las prácticas locales se considera socialmente beneficioso. A pesar de que muchas de las prendas de influencia europea no se ajustaban a las condiciones climáticas de Costa Rica, la incomodidad de llevar estos distintivos de clase tenía una interpretación positiva: “¿Por qué lo hacían? Evidentemente, porque la ropa oscura, pesada, distintivamente europea, era signo de modernidad, civilización y aristocracia" (Bauer, 2002, p. 214). Por todo lo anterior, es importante entender la moda como un objeto enclasante, es decir, un objeto que ayuda a generar la distinción entre las clases sociales. Costa Rica se sumó a esta práctica reforzada con la información que los figurines traían desde Europa o los Estados Unidos.

Finalmente, la realización de este proyecto evidenció nuevas y variadas rutas de investigación. Los figurines del acopio contienen una enorme cantidad de información tanto en sus 
textos como en sus ilustraciones, la que puede servir de base para estudiarlos desde muchos puntos de vista. Por ejemplo, es posible investigar acerca de la utilización del corsé y de las prendas formadoras del cuerpo femenino e infantil como una forma de encarnar físicamente los ideales de belleza y de comportamiento propios del fin del siglo XIX. También pueden descubrirse los aspectos ideológicos que se hacían evidentes en el cuerpo femenino formado por el corsé. Por otra parte, las ilustraciones de moda ofrecen enormes posibilidades de estudio de la imagen: pueden estudiarse como idealizaciones del cuerpo femenino; como evidencias de los espacios permitidos a la mujer en este período; así como parte de un revolucionario proceso de aceleramiento en la producción y el consumo de las imágenes dentro de la evolución del capitalismo.

Asimismo, la gran cantidad de anuncios comerciales ubicados dentro de las revistas del acopio permite realizar un estudio de los productos ofrecidos para las mujeres de la época. Los anuncios también indican las formas en las que las mujeres podían realizar procesos de cuidado de sus cuerpos, cabellos y rostros: maquillaje, perfumería, limpieza, tonificación y curación de variados padecimientos "femeninos". El universo de lo femenino se presenta inusualmente complejo y rico en detalles en los figurines de moda, los cuales pueden ayudar a crear un panorama más amplio de las exigencias sociales planteadas a las mujeres en los últimos años del siglo XIX. Esta época representa el fin de la era victoriana, pero a la vez, el inicio de la modernidad del siglo XX, por lo cual sus cambios y repercusiones serán de vital importancia para el establecimiento de la feminidad moderna.

\section{Referencias}

Anuncio de la costurera Rafaela Cantillo [fotografía]. En La República (14 de agosto de 1897).

Anuncio de La Estación. En El Correo de Costa Rica (23 de diciembre de 1888). Recuperado de http://www.sinabi.go.cr/

Anuncio de la Librería Moderna [fotografía]. En El Pabellón Español (10 de noviembre de 1895). Recuperado de http://www.sinabi.go.cr/.

Anuncio de La Moda Elegante [fotografía]. En El anunciador costa-ricense. (16 de junio de 1891). Recuperado de http://www.sinabi.go.cr/.

Anuncio de la tienda por departamentos parisiense Au Bon Marché [fotografía]. En La Moda Elegante. (30 de marzo de 1892).

Anuncio de La Villa de París [fotografía]. En La República. (8 de agosto de 1897).

Anuncio de máquinas de coser en la tienda Uribe y Batalla [fotografía]. En El Anunciador costa-ricense (1 de setiembre de 1889). Recuperado de: http://www.sinabi.go.cr/. 
Anuncio de productos importados de París [fotografía]. El Heraldo (8 de octubre de 1897).

Bauer, Arnold J. (2002). Somos lo que compramos: Historia de la cultura material en América Latina. México D. F.: Altea Taurus.

Blusa de tejido jersey para viaje [fotografía]. La Estación, (16 de junio de 1889).

Boucher, F. (1997). A History of Costume in the West. Londres: Thames \& Hudson.

Bourdieu, P. (2016). La distinción: Criterios y bases sociales del gusto. Barcelona: Taurus.

Corsé [fotografía]. En La Estación. (1 de octubre de 1889).

Distintivo en la tapa de la encuadernación [fotografía]. En La Revista Ilustrada de Nueva York. (1889).

"Dos mujeres" [fotografía]. Rudd y Paynter, s.f. (№ de registro 977). En Museo Nacional de Costa Rica.

"Dos señoritas" [fotografía]. Rudd y Paynter. En Museo Nacional de Costa Rica. (s.f.). No de registro 1006.

Elias, N. (2000). The Civilizing Process: Sociogenetic and Psychogenetic Investigations (Ed. rev.). Massachusetts: Blackwell Publishing.

Enagua de surah [fotografía]. En La Moda Elegante (s.f.).

Groom, G. (ed.) (2012). Impressionism, Fashion and Modernity. Chicago: The Art Institute of Chicago/Yale University Press.

Miller, M. B. (1981). The Bon Marché. Bourgeois Culture and the Department Store 1869-1920. Princeton / New Jersey: Princeton University Press.

Portada de La Estación [fotografía]. En La Estación. (febrero de 1889).

Portada de La moda elegante [fotografía]. En La moda elegante. (setiembre de 1892).

Portada de La Revista Ilustrada de Nueva York [fotografía]. En La Revista Ilustrada de Nueva York. (enero de 1889).

Rose, C. (2014). Art Nouveau Fashion. Londres: V\&A Publishing.

Ross, R. (2008). Clothing. A Global History. Cambridge: Polity Press.

"Señora de Tinoco" [fotografía]. Anónimo, s.f. (№ de registro 28887). En Museo Nacional de Costa Rica.

Traje con cola medio larga para señora de cierta edad [fotografía]. En La Estación. (16 de setiembre de 1889). 
Vega Jiménez, P. (1991). De la banca al sofá, la diversificación de los patrones de consumo en San José (1857-1861). Revista de Historia, (24), pp. 53-87.

Vega Jiménez, P. (1995). De la imprenta al periódico. Los inicios de la comunicación impresa en Costa Rica (1821-1850). Costa Rica: Editorial Porvenir.

Vega Jiménez, P. (1998). Recién llegado de Europa: El consumo en San José al finalizar el siglo XIX (1887-1898). Ponencia. IV Congreso Centroamericano de Historia, Managua, julio 1999

Vestido de calle [fotografía]. En La Moda Elegante. (22 de noviembre de 1892). 